УДК $551.242 / 243+553.078+553.41$

\title{
ПРОДУКТИВНОСТЬ ЗОЛОТОРУДНО-РОССЫПНЫХ УЗЛОВ ОМОЛОНСКОГО И ПРИКОЛЫМСКОГО ТЕРРЕЙНОВ (Северо-Восток Азии)
}

\author{
Глухов А. Н. \\ ФГБУН Северо-Восточный комплексный научно-исследовательский институт \\ им. Н. А. Шило ДВО РАН, г. Магадан \\ E-mail: gluhov76@list.ru
}

\begin{abstract}
Рассмотрено влияние тектоники и геодинамической эволюции докембрийских террейнов на продуктивность руд и россыпей на примере Омолонского массива и Приколымского поднятия. Кратко охарактеризованы геолого-генетические типы оруденения, приведены параметры рудно-россыпных узлов. Показано, что Омолонский массив представляет собой золоторудную, а Приколымское поднятие золотороссыпную металлогенические зоны. Обусловлено это принципиальными различиями тектонической структуры и геодинамической природы этих террейнов. Первый представляет собой жесткую структуру, консолидированную к началу неопротерозоя. Второй - составной террейн, близкий по строению к складчато-надвиговому поясу. Сделан вывод, что многие черты металлогении докембрийских террейнов объясняются особенностями их тектоники и геодинамической эволюции. В частности, продуктивность золоторудно-россыпных узлов находится в зависимости от наличия консолидированного дорифейского фундамента. Эта зависимость реализуется через морфологию и условия залегания рудных тел и рудоконтролирующих разломов, глубину их проникновения, спектр геолого-генетических типов минерализации и ее богатство.
\end{abstract}

Ключевые слова: золоторудно-россыпной узел, террейн, продуктивность, рудогенез, докембрий, консолидированный, чешуйчато-надвиговый, разлом, рудоконтролирующий.

DOI: $10.34078 / 1814-0998-2020-3-11-27$

Рудные месторождения образуются в результате процессов перераспределения вещества мантии и земной коры, которые сопровождаются длительной тектонической и флюидной активностью (Овчинников, 1990). В этом контексте изучение структур длительного развития (начиная с архея и раннего протерозоя) актуально для понимания взаимосвязи тектогенеза и эволюции рудообразования и рудоконтролирующих структур

В рамках аккреционной тектоники (Геодинамика..., 2006) структура Северо-Востока Азии предстает как совокупность орогенных поясов, взаимодействующих с окраиной СевероАзиатского кратона (САК). Среди террейнов различной природы здесь выделяются кратонные и миогеоклинальные, представляющие собой фрагменты САК. Наиболее крупные среди них - Омо-

(C) Глухов А. Н., 2020 лонский кратонный террейн (или Омолонский массив, далее - ОМ) и Приколымский миогеоклинальный террейн (традиционно именуемый также Приколымским поднятием, далее - ПК). Оба они входят в состав орогенных поясов СевероВостока Азии позднеюрско-раннемелового возраста: ПК - Яно-Колымского (Геодинамика..., 2006), ОМ - Охотско-Корякского (Горячев и др., 2017) и имеют длительную историю геологического развития: наиболее древние U-Pb датировки комплексов первого составляют 2.4 млрд (Беус, Миледин, 1990), второго - 3.4 млрд лет (Бибикова и др., 1978) лет. Рудные концентрации здесь формировались в течение длительного времени и явились функцией широкого спектра породо- и рудообразующих процессов.

Как известно, «определенные типь месторождений проявляются при определенных тектонических режимах в определенных типах тек- 
тонических структур» (Щеглов, 1989. С. 10), т. е. рассмотрение рудогенеза не может происходить в отрыве от тектоники. Металлогения докембрийских террейнов Северо-Востока Азии в контексте влияния на нее особенностей тектонического строения и геодинамического развития изучена недостаточно. В ограниченном числе публикаций, которые принадлежат одному коллективу исследователей, развиваются представления о тождественности факторов рудогенеза докембрийских террейнов - кратонных и пассивной континентальной окраины (Сидоров и др., 2008, 2012; Сидоров, Волков, 2015). Как идентичные традиционно рассматриваются и факторы, контролирующие размещение и параметры россыпей золота ОМ и ПК (Толпегин, Генкин, 1974; Россыпные..., 1997).

Ранее было показано влияние тектонических условий рудогенеза на структуру и морфологию рудных образований ОМ и ПК (Глухов, 2019). Рассмотрение влияния региональной тектоники на продуктивность руд и россыпей даст дополнительную информацию для суждений о факторах рудоконтроля и влиянии на них геодинамических факторов. В основу нашего анализа положены сведения о запасах, прогнозных ресурсах и количестве добытого из россыпей золота, почерпнутые из отчета М. Е. Городинского (2004 г.), а также опубликованные данные о запасах рудных месторождений Омолонского массива (Официальный сайт..., 2019). Использованы также фактический материал и результаты его обработки и интерпретации, собранные автором при проведении полевых и камеральных работ на Приколымье в 2007-2011 гг. и на Омолонском массиве в 2015-2017 гг.

Термин «рудный узел» в данной работе, в соответствии с Геологическим словарем (2010), обозначает рудоносную площадь, отчетливо выделяющуюся на фоне слабо минерализованной окружающей территории и имеющую размеры

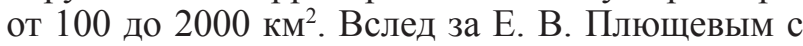
соавторами мы рассматриваем рудный узел, прежде всего, как «аномально рудоносный блок земной корыл (Плющев и др., 2016. С. 78), т. е. природный феномен, а не геолого-экономическое подразделение. Под «рудно-россыпным узлом» мы, соответственно, понимаем рудный узел, в пределах которого известны промышленные россыпные концентрации металла; т. е. руднороссыпной узел - частный случай рудного узла. Часто, когда металлоносность узла полностью определяется россыпными концентрациями, говорят о «россыпных узлах» (Полеванов, 1988а). Однако коренные источники, даже если они неизвестны, тем не менее существовали, имели геолого-генетический тип; их проекцией является россыпь со всеми своими особенностями, включая типоморфизм и минеральные ассоциации самородного золота (Савва, Прейс, 1990). Рудный или рудно-россыпной район - это металлогенический таксон более высокого уровня, объединяющий несколько рудных узлов. Таким образом, в данной работе мы предлагаем изучение золоторудно-россыпных узлов и районов как инструмент для выявления региональных металлогенических закономерностей. Подобный подход сам по себе не нов и применялся ранее к другим золотоносным регионам (Третьякова, 2010; Степанов, Мельников, 2017).

\section{ГЕОЛОГИЧЕСКОЕ СТРОЕНИЕ ОМОЛОНСКОГО ТЕРРЕЙНА}

В структуре ОМ (рис. 1) выделяются три яруса: дорифейский кристаллический фундамент, рифей - палеозойский чехол, сложенный терри-

Puc. 1. Тектоно-минерагеническая схема Омолонского террейна (Глухов, 2019, с дополнениями): 1 - дорифейский кристаллический фундамент; 2 - рифейско-среднеюрский и верхнеюрско-меловой структурный ярусы; 3, 4- вулканогенные пояса (3 - Кедонский, 4 - Охотско-Чукотский и Олойский); 5 - террейны складчатого обрамления (КН - Куларо-Нерский, ВЛ - Вилигинский, ЕР - Еропольский); 6 - гранитоиды; 7 - разломы; 8-13 месторождения и рудопроявления различных геолого-генетических типов: 8 - железистые кварциты, 9 - железорудные скарны, 10 - медно- и молибден-порфировые, 11 - серебро-полиметаллические, 12 - эпитермальные золото-серебряные, 13 - мезотермальные золото-полиметаллические и золото-редкометалльные; 14 - границы рудно-россыпных районов, 15 - границы Конгинской зоны ТМА

Арабскими цифрами обозначены номера месторождений и рудопроявлений, упомянутые в тексте и таблицах: 1 - Кубака, 2 - Биркачан, 3 - Ольча, 4 - Бургали, 5 - Елочка, 6 - Эвенское, 7 - Дальнее, 8 - Ирбычан, 9 - Невенрекан, 10 - Ороч, 11 - Джелты, 12 - Нижний Биркачан, 13 - Захаренко, 14 - Орлиное, 15 - Вулкан, 16 - Седое, 17 - Табор, 18 - Вечернее, 19 - Хрустальное, 20 - Прогнозное, 21 - Хивач, 22 - Коаргычан, 23 - Любимое, 24 - Туманное, 25 - Надежда, 26 - Юное, 27 - Маловодное, 28 - Рыжик, 29 - Дручак, 30 - Аура, 31 - Радуга

Римскими цифрами обозначены номера рудно-россыпных узлов: I - Чайнинский, II - Рассошинский, III - Верхне-Булунский, IV - Бургачанский, V - Джугаджакский, VI - Верхне-Бургагчанский, VII - ЛевоКедонский, VIII - Биркачанский, IX - Закоронный, X - Анмандыканский, XI - Ольдянинский, XII - ВерхнеКоаргычанский

Fig. 1. Tectonic and mineragenic scheme of the Omolon terrain (Glukhov, 2019, amended): 1 - Preriphean cristalline basement; 2 - Riphean - Mid-Jurassic and Upper-Jurassic - Cretaceous structural levels; 3, 4 - volcanic belts (3 - 


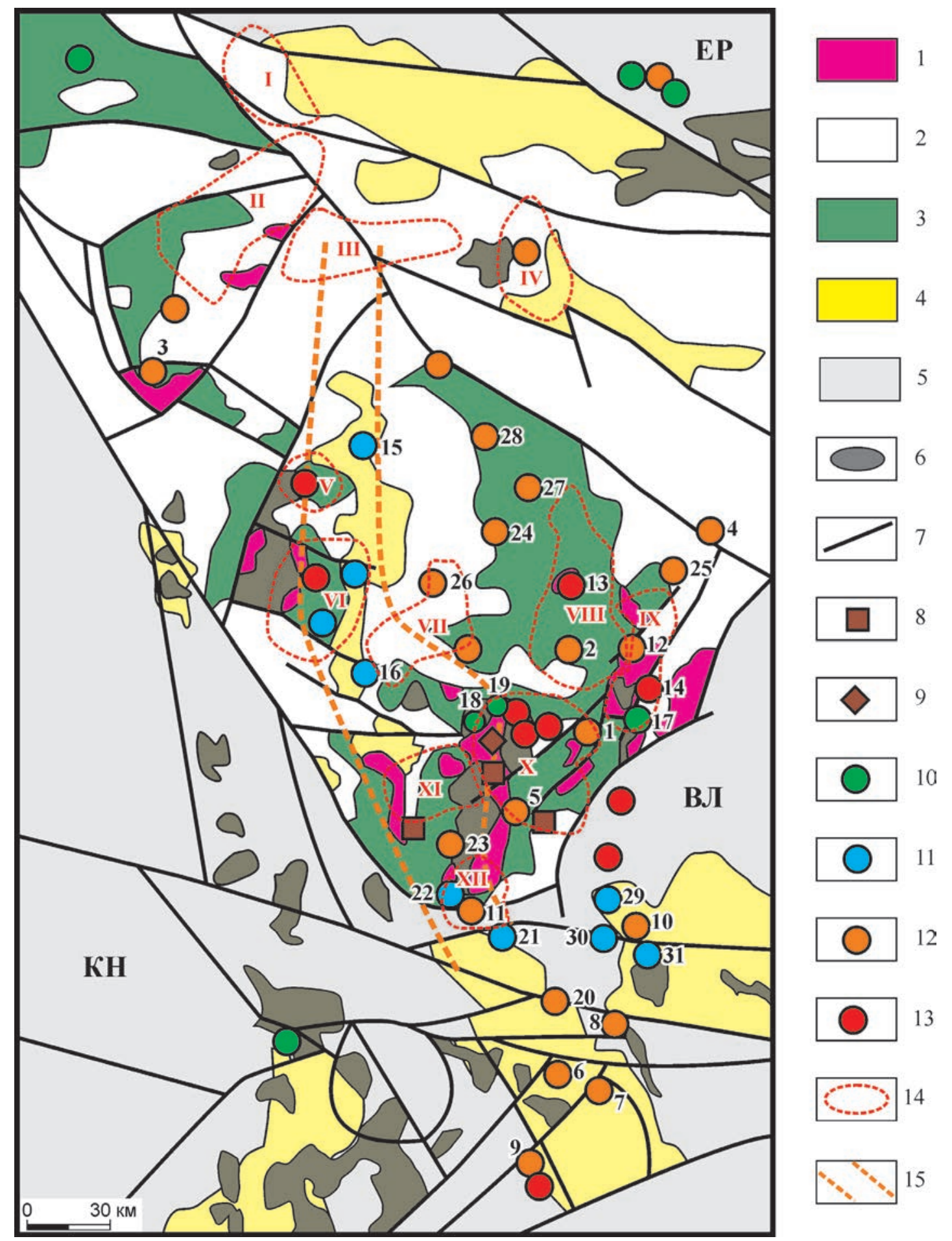

Kedon, 4 - Okhotsk-Chukotka, and Oloy); 5 - folded framing terrains (KH - Kular-Nera, ВЛ - Viliga, EP - Yeropol); 6 - granitoids; 7 - faults; 8-13-geologically and genetically different ore deposits and occurences: 8 - BIF, 9 - Feskarn, 10 - Cu-Mo porphyry, 11 - Ag-polymetallic, lode 12 - epithermal Au-Ag, 13 - mesothermal Ag-polymetallic and Ag-rare metallic; 14 - boundaries of ore-placer districts; 15 - Kongina tectonic zone boundaries

Numbers of deposits: 1 - Kubaka, 2 - Birkachan, 3 -Olcha, 4 - Burgali, 5 - Yolochka, 6 - Evenskoye, 7 - Dal'neye, 8 - Irbychan, 9 - Nevenrekan, 10 - Oroch, 11 - Dzhelty, 12 - Nizhniy Birkachan, 13 - Zakharenko, 14 - Orlinoye, 15 Vulcan, 16 - Sedoye, 17 - Tabor, 18 - Vecherneye, 19 - Khrustal'noye, 20 - Prognoznoye, 21 - Khivach, 22 - Koargychan, 23 - Lyubimoye, 24 - Tumannoye, 25 - Nadezhda, 26 - Yunoye, 27 - Malovodnoye, 28 - Ryzhik; 29 - Druchak, 30 - Aura, 31 - Raduga

Numbers of ore-placer knots: I - Chayninsky, II - Rassoshinsky, III - Verkhne-Bulunsky, IV - Burgachansky, V Dzhugadzhaksky, VI - Verkhne-Burgagchansky, VII - Levo-Kedonsky, VIII - Birkachansky, IX - Zakoronny, X - Anmandykansky, XI - Ol'dyaninsky, XII - Verkhne-Koargychansky 
генными и карбонатными толщами, и мезозойский ярус, сложенный вулканогенными и осадочными комплексами. На них наложены вулканиты Кедонского (КВП), Олойского (ОВП) и ОхотскоЧукотского (ОЧВП) окраинно-континентальных поясов. Стратифицированные комплексы прорывают крупные батолиты, относимые к двум интрузивным комплексам - абкитскому (силур) и булунскому (ранний карбон).

Наиболее древние породы ОМ представлены плагиогнейсами и амфиболитами ноддинского комплекса с абсолютными U-Pb и $\mathrm{Pb}-\mathrm{Pb}$ возрастами 2.96-3.40 млрд лет (Бибикова и др., 1978; Шевченко, 2006; Акинин, Жуланова, 2016); гнейсы, амфиболиты и кристаллические сланцы ауланджинского комплекса имеют U-Pb возраст 1.99-2.25 млрд лет (Шевченко, 2006). Их перекрывают раннепротерозойские (U-Pb возраста 1.91-2.03 млрд лет; Шевченко, 2006) метабазиты батикского комплекса, внедрение которых отра-зилось в изотопных датировках цирконов из архейских комплексов (Акинин, Жуланова, 2016). Консолидация дорифейского кристаллического фундамента ОМ маркируется гранитизацией и внедрением габброидов стрелкинского комплекса ( $\mathrm{Rb}-\mathrm{Sr}$ возраст $1479 \pm 31$ млн лет; Шевченко, 2006).

Терригенно-карбонатные толщи рифея - нижнего палеозоя и вулканогенно-терригенно-карбонатные отложения, сформированные в интервале от позднего палеозоя до раннего мезозоя, слагают чехол ОМ. Индикатором стабильной плитной обстановки, существовавшей на ОМ в интервале от позднего кембрия до силура, явились крупные интрузии сиенитов с абсолютным $\mathrm{Rb}-\mathrm{Sr}$ возрастом $537 \pm 27$ млн лет (Горячев и др., 2017). Коллизионные гранитоиды (Rb-Sr возраст 420 $\pm 14-425 \pm 160$ млн лет; Горячев и др., 2017) слагают крупные батолитоподобные массивы. Известково-щелочные магматические ассоциации надсубдукционного КВП формировались в интервале с раннего девона (U-Pb датировка вулканитов из основания которого составля-

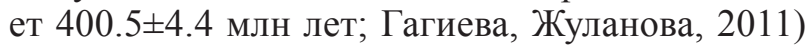
по ранний карбон ( $\mathrm{Rb}-\mathrm{Sr}$ возраст гранитоидов $321 \pm 8$ млн лет; Горячев и др., 2017). Позднемезозойские надсубдукционные комплексы ОВП и ОЧВП местами далеко проникают в пределы ОМ (Конгинская зона). Позднемезозойские щелочные габброиды и сиениты имеют рифтогенную природу (Дылевский, 1997).

Строение дорифейского фундамента ОМ определяют моноклинали и гранито-гнейсовые купола (Шевченко, 2006) с крутопадающими границами. Породы рифейско-среднеюрского чехла образуют, напротив, пологие моноклинали и брахисинклинали. Вулканиты слагают отрицательные и положительные вулканострук- туры диаметром 10-30 км. Наиболее крупные разломы характеризуются крутым падением и взбросо-сдвиговой кинематикой. Примером является Верхне-Омолонский глубинный разлом, образованный крутопадающими (30-75²) взбросами, образующими зону протяженностью более 100 км и шириной до 15 км. Взбросы и надвиги известны в южной и западной частях $\mathrm{OM}$, где по ним пермские толщи надвинуты на отложения мезозоя. Другие разломы северо-восточного простирания представляют собой крутопадающие сбросы и сдвиги.

В деформационной истории ОМ мы выделяем пять этапов (табл. 1). Характер тектонических деформаций и состав вещественных комплексов отражают стабильную, консолидированную структуру террейна, сформировавшуюся к началу рифея. Сменявшие друг друга эпохи сжатия и растяжения при этом не приводили к существенным деформациям, изменявшим структурный рисунок; они лишь способствовали формированию субвертикальных расколов кристаллического фундамента, иногда глубоко проникавших в глубь массива.

\section{ГЕОЛОГИЧЕСКОЕ СТРОЕНИЕ ПРИКОЛЫМСКОГО ТЕРРЕЙНА}

Наиболее древними породами ПК (рис. 2) являются амфиболиты, плагиогнейсы, метабазиты и перидотиты с $\mathrm{Pb}-\mathrm{Pb}$ возрастом 2.062.36 млрд лет (Щербакова и др., 1988; Беус, Миледин, 1990), слагающие тектоническую пластину, приуроченную к зоне регионального надвига. С ними ассоциируют гнейсо-граниты $\mathrm{c} \mathrm{Pb}-\mathrm{Pb}$ возрастом 1.70-1.90 млрд лет (Беус, Миледин, 1990). Близкий U-Pb возраст ( $1710 \pm 21$ млн лет) имеют риолиты, ранее считавшиеся позднерифейскими (Худолей и др., 2006). Региональный метаморфизм раннепротерозойских пород происходил в условиях амфиболитовой фации. Комплексы позднего протерозоя сложены песчаниками, филлитами, карбонатными породами; среди них широко развит динамотермальный метаморфизм зеленосланцевой фации. Докембрийские образования перекрыты терригенными, вулканогенно-осадочными и карбонатными породами палеозоя - мезозоя. Интрузивные комплексы представлены мелкими телами девонских и меловых гранитоидов, а также дайками позднемеловых базитов. Состав вещественных комплексов ПК отражает существовавшую здесь, начиная с рифея, обстановку пассивной континентальной окраины (Шпикерман, 1998) с циклически проявленным (рифей, кембрий, средний палеозой) рифтогенезом (Булгакова, 1991), изредка осложнявшуюся субдукционными (Трунилина и др., 2004) и коллизионными (Горячев, 1998) событиями. 


\begin{tabular}{|c|c|c|c|c|c|c|c|c|}
\hline 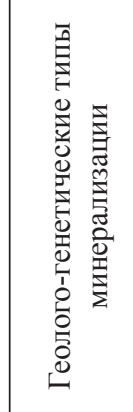 & 1 & 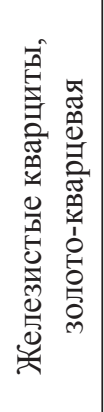 & 1 & 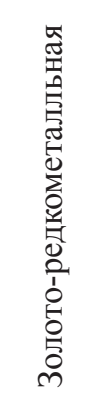 & 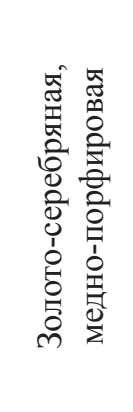 & 1 & 1 & 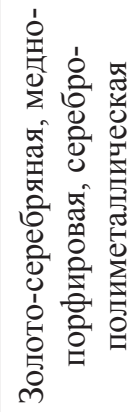 \\
\hline 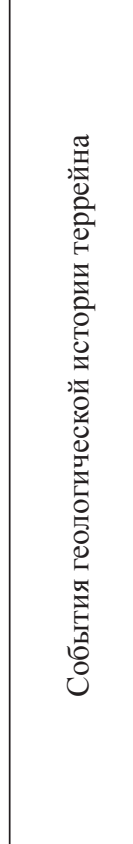 & 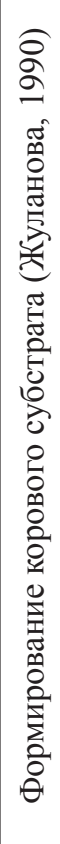 & 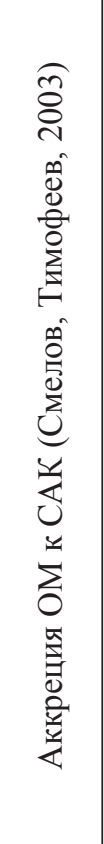 & 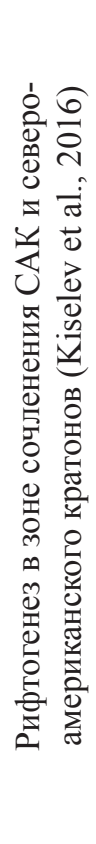 & 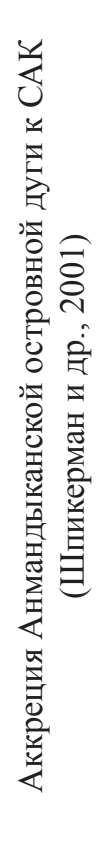 & 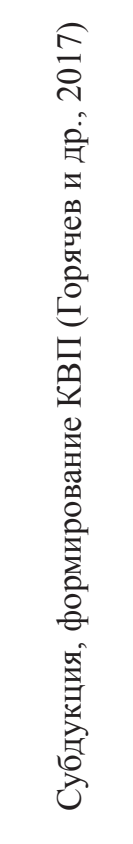 & 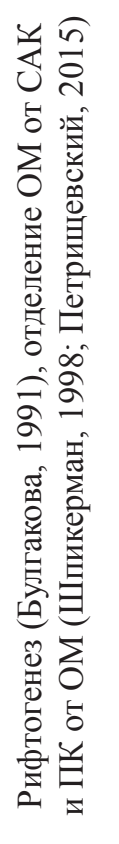 & 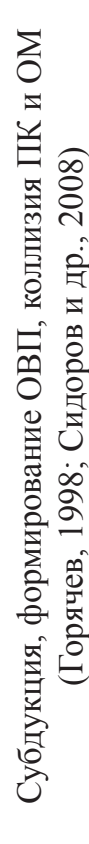 & 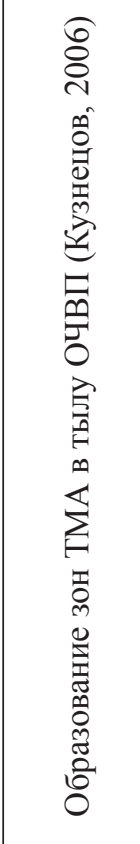 \\
\hline 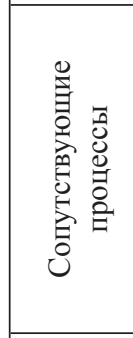 & 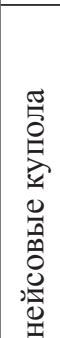 & 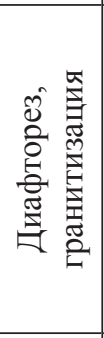 & 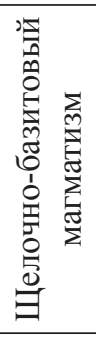 & 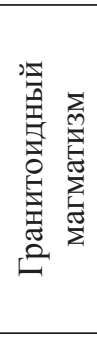 & 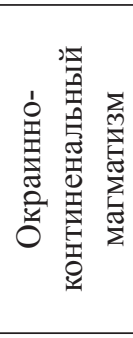 & 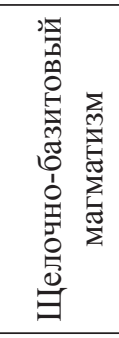 & 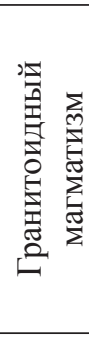 & 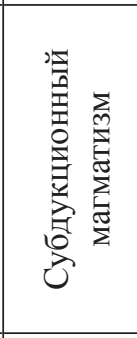 \\
\hline 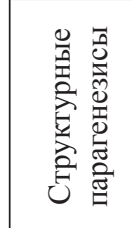 & 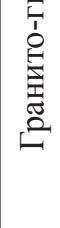 & 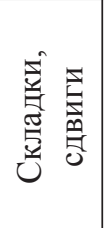 & 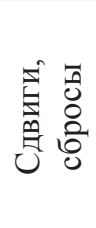 & I & 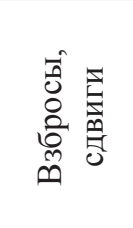 & 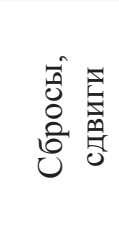 & 志 & 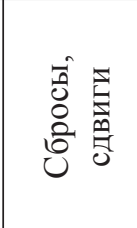 \\
\hline 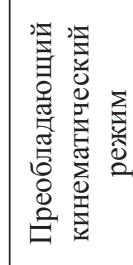 & c. & 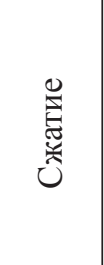 & 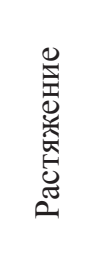 & 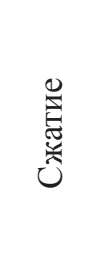 & 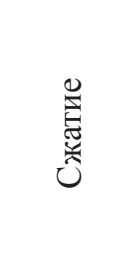 & 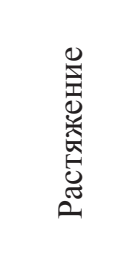 & 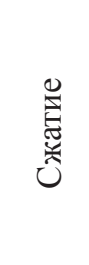 & 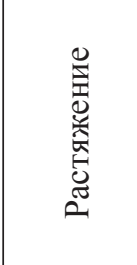 \\
\hline 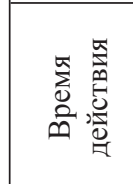 & $\widetilde{\alpha}^{\prime}$ & $\begin{array}{l}\frac{5}{2} \\
\frac{a}{2} \\
\frac{\alpha}{2}\end{array}$ & $\mathrm{~N}^{-1}$ & $\stackrel{N}{ }$ & $\mathrm{~N}^{N}$ & $\begin{array}{l}\sum_{1}^{N} \\
N^{N}\end{array}$ & $\stackrel{51}{1}$ & $v^{\frac{9}{4}}$ \\
\hline 氶 & $\neg$ & $N$ & $m$ & $\nabla$ & مL & 0 & $\Lambda$ & $\infty$ \\
\hline
\end{tabular}



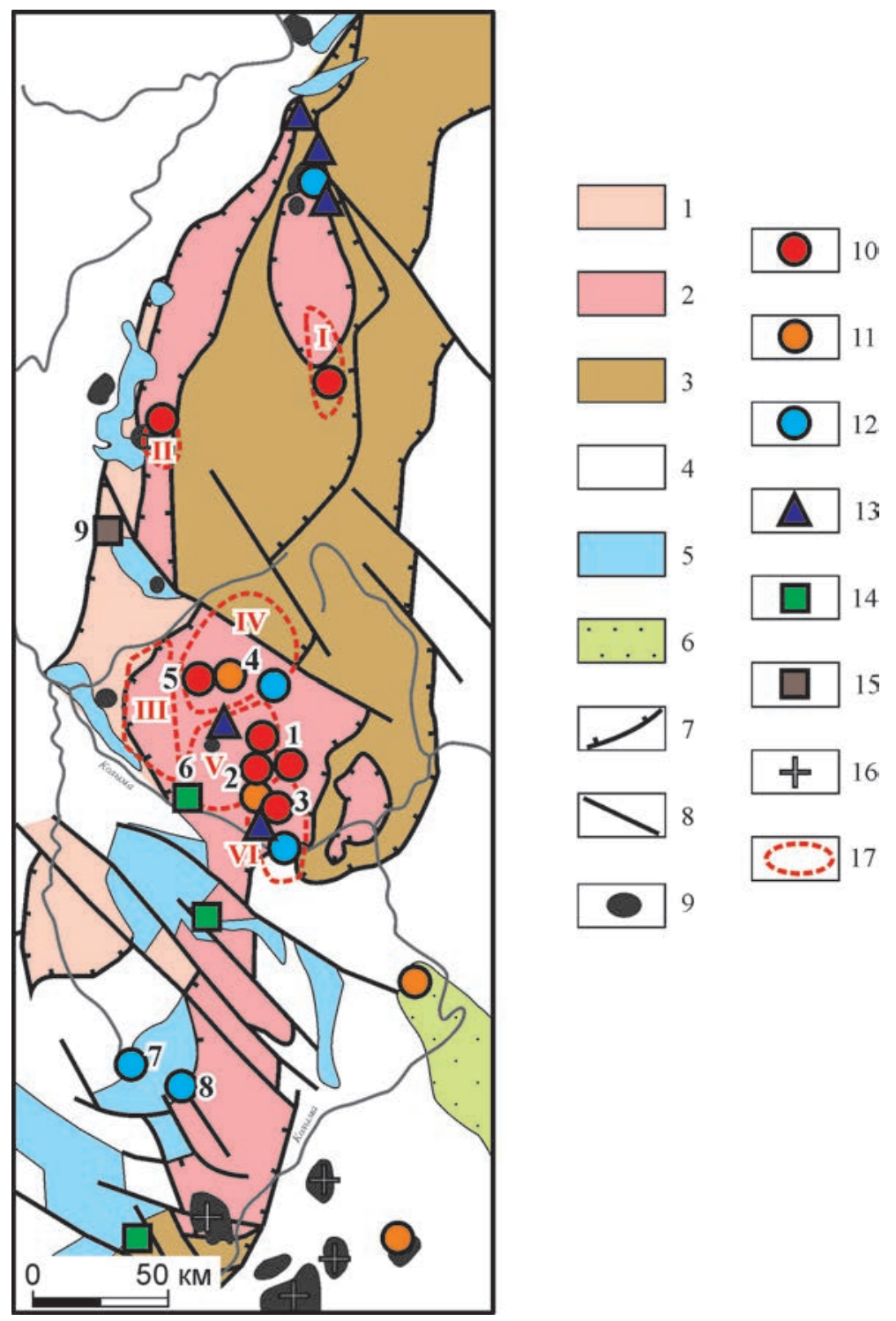

Рuc. 2. Тектоно-минерагеническая схема Приколымского террейна и смежных структур (Глухов, 2019, с изменениями): 1-3 - Приколымский террейн, субтеррейны: 1 - Спиридоновский, 2 - Шаманихинский, 3 - Ярходонский; 4 - прочие террейны; 5 - УяндиноЯсачненский вулканогенный пояс; 6 Балыгычано-Сугойский рифтогенный прогиб; 7 - надвиги; 8 - крутопадающие разломы; 9 - позднепалеозойские и мезозойские гранитоиды; 10-16 - месторождения и рудопроявления различных геологогенетических типов: 10 - мезотермальные жильные и штокверковые Au, 11 - эпитермальные жильные и штокверковые $\mathrm{Au}$ $\mathrm{Ag}, 12$ - штокверковые и жильные $\mathrm{Cu}-\mathrm{Pb}$ $\mathrm{Zn}, 13$ - стратиформные $\mathrm{Pb}-\mathrm{Zn}, 14$ - стратиформные $\mathrm{Cu}, 15$ - стратиформные $\mathrm{Fe}$, 16 - жильные и штокверковые $\mathrm{Sn} ; 17$ рудно-россыпные узлы. Арабскими цифрами обозначены месторождения и рудопроявления: 1 - Надежда, 2 - Темное, 3 - Тый-Юрье, 4 - Тимша, 5 - Сохатиное, 6 - Ороек, 7 - Невидимка, 8 - Опыт, 9 Победа. Римскими цифрами обозначены рудно-россыпные узлы: I - Каменский, II - Право-Эджекальский, III - Чилистяхский, IV - Глуховский, V - Глухаринский, VI - Савельевский

Fig. 2. Tectonic and mineragenic scheme of the Kolyma terrain and adjacent structures (Glukhov, 2019, amended): 1-3 - Kolyma terrain, subterrains: 1 - Spiridonova, 2 -Shamanikha, 3 - Yarkhodon; 4 - other terrains; 5 -Uyandina-Yasachnaya volcanic belt; 6 - Balygychan-Sugoy rift-induced trough; 7 - trusts; 8 - high-angle faults; 9 - Late Paleozoic and Mesozoic granitoids; 10-16 geologically and genetically different mineral deposits and occurences; 10 - mesothermal lode and stockwork Au, 11 - epithermal lode and stokwork Au-Ag, 12 - stokwork and lode $\mathrm{Cu}-\mathrm{Pb}-\mathrm{Zn}, 13$ - stratiform Pb-Zn, 14 - stratiform $\mathrm{Cu}, 15$ - stratiform Fe, 16 - lode and stokwork Sn; 17 - ore-placer knots. Numbers of the deposits: 1 - Nadezhda, 2 - Temnoye, 3 - Tiy-Yurye, 4 - Timsha, 5 - Sokhatinoye, 6 - Oroyok, 7 - Nevidimka, 8 - Opyt, 9 - Pobeda. Numbers of ore-placer knots: I - Kamensky, II - Pravo-Edzhekalsky, III - Chilistyakhsky, IV - Glukhovsky, V - Glukharinsky, VI - Savelyevsky

В структурном отношении ПК представляет собой гигантский аллохтон, образованный пакетами надвиговых чешуй (Шпикерман, 1998; Хаин и др., 2009) центриклинального падения. Результаты структурно-тектонофизических исследований (Глухов и др., 2012; Третьяков, 2016), а также данные по U-Pb датированию и (U/Th)/He низкотемпературной термохронологии обломочных цирконов (Прокопьев и др., 2019) позволяют выделить четыре деформационных этапа, которые коррелируют с геодинамическими обстановками (табл. 2). В структуре ПК наиболее древние раннепротерозойские комплексы дислоцированы и метаморфизованы совместно с рифейско-вендскими. Это принципиально отличает ПК от кратонных террейнов, например, от ОМ. Все этапы формирования тектонической структуры Приколымья четко параллелизуются с главными этапами развития северо-восточной окраины САК - позднепалеозойским и мезозойским.

\section{МЕТАЛЛОГЕНИЧЕСКИЕ ОСОБЕННОСТИ ТЕРРЕЙНОВ}

Для ОМ характерно, главным образом, жильно-прожилковое оруденение. Наиболее многочисленными и изученными являются золоторудные месторождения и проявления, сформировавшиеся в две металлогенические эпохи: средне-, позднепалеозойскую и позднемезозойскую (Мерзляков и др., 1984). 


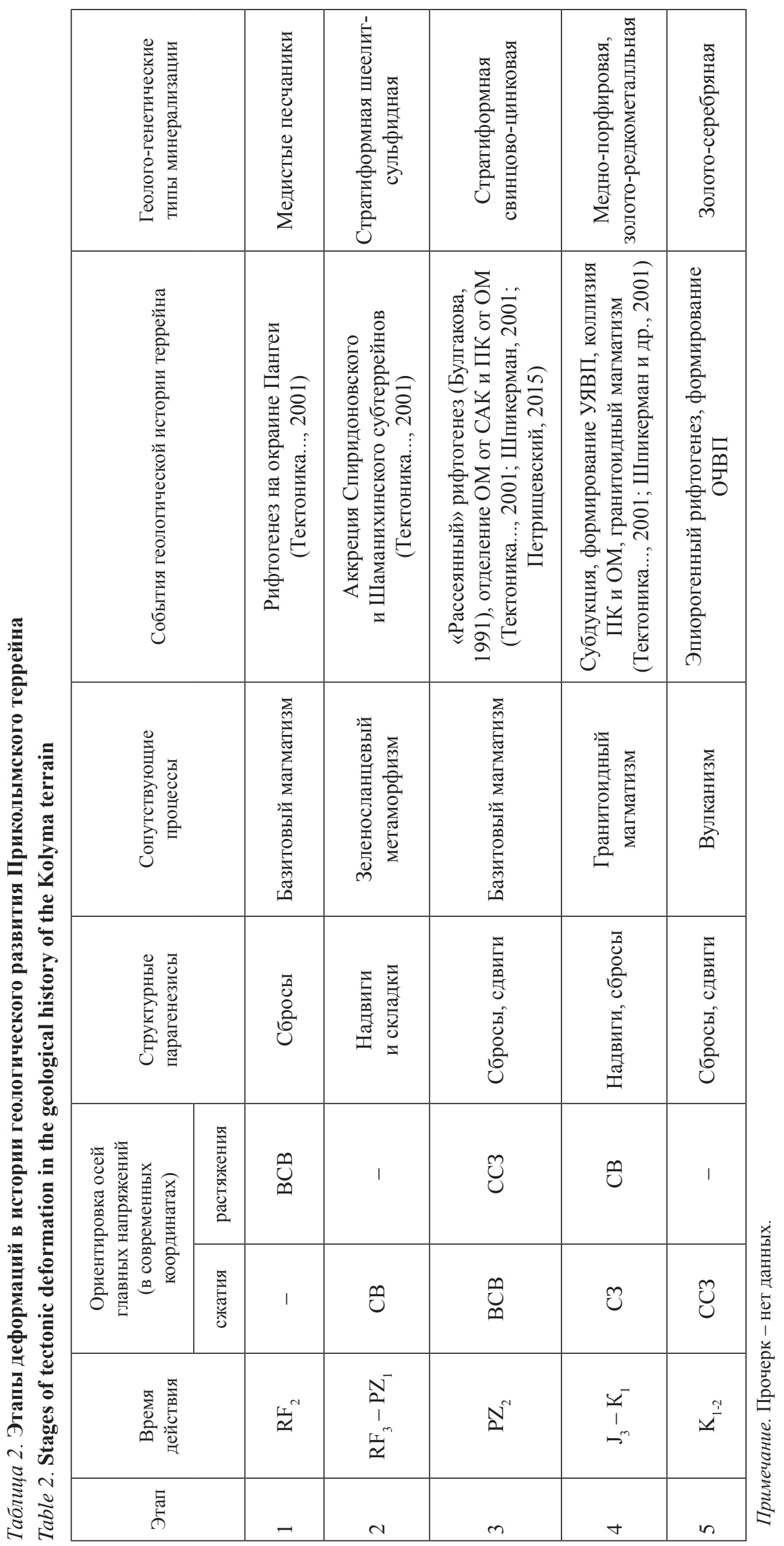


Основная часть месторождений и рудопроявлений золота вмещается вулканитами КВП, ОВП и ОЧВП, а также палеозойскими гранитоидами.

Палеозойские эпитермальные золото-серебряные месторождения и рудопроявления ассоциируют с вулканитами КВП и сгруппированы в два рудных района (Кубакинский, Кедонский) и один изолированный рудный узел (Хебикенджинский). Наиболее изучены месторождения Кубака (Степанов, Шишакова, 1994; Черняев, Черняева, 2001) и Ольча (Савва, Шахтыров, 2011). Размещение минерализации контролируется очертаниями крупных (20-40 км в диаметре) вулкано-тектонических депрессий, выполненных преимущественно кислыми вулканитами и вулканогенно-осадочными отложениями позднедевонско-раннекаменноугольного возраста. Рудные тела представлены крутопадающими адуляр-карбонат-кварцевыми жилами, которые по вертикали сменяются жильнопрожилковыми зонами. Специфической особенностью руд является низкая сульфидность руд, не превышающая 3-5\%, а для наиболее крупных месторождений (Кубака, Биркачан) составляющая $0.1-0.5 \%$ (Волков и др., 2016). Золото-серебряное отношение в рудах колеблется от 1:2 до 1:5. Главными минералами продуктивного парагенезиса являются самородное золото и электрум; роль сульфосолей серебра незначительна. Многие месторождения и рудопроявления сопровождаются россыпями (Биркачан, Магнитное, Юное).

Палеозойская мезотермальная золото-редкометалльная минерализачия образует Рассошинский рудный район, Абкитский, Джугаджакский и Ольдянинский рудные узлы. Рудопроявления (Горячев и др., 2017) располагаются в эндоконтактовых зонах гранитоидных плутонов анмандыканского и абкитского комплексов и представлены крутопадающими жилами и прожилково-жильными зонами сульфиднокарбонат-кварцевого. Они представлены жилами и прожилково-жильными зонами полевошпаткварцевого, сульфидно-карбонат-кварцевого и флюорит-сульфидно-кварцевого состава с молибденитом, блеклым рудами, теллуридами Аu и $\mathrm{Ag}$, самородным золотом. Многие рудопроявления сопровождаются россыпями.

Медно-порфировые рудопроявления связаны с палеозойскими и мезозойскими гранитоидами. К интрузиям диорит-порфиритов, гранит-порфиров и риолитов приурочены ореолы пропилитов и аргиллизитов со вкрапленностью пирита, халькопирита, молибденита, а также зоны сульфидно-карбонаткварцевых прожилков с медно-полиметаллической и золото-серебряной минерализацией (Кораго, Лычагин, 1977; Горячев и др., 2017), которые сопровождаются россыпями.
Конгинская зона ОЧВП, которая рассекает ОМ в меридиональном направлении (Кузнецов, 2006), контролирует размещение медномолибден-порфировых (Вечернее, Хрустальное) и серебро-полиметаллических (Вулкан, Седое) рудопроявлений.

На всех выступах дорифейского кристаллического фундамента ОМ присутствуют железистыле кварииты (Фадеев, 1975).

Всего на ОМ известно 12 рудно-россыпных узлов (см. рис. 1; табл. 3), существенно различающихся как по типу коренных источников, так и по продуктивности.

Разнообразие геолого-генетических типов золотого оруденения и многоэтапность его формирования нашли свое отражение в составе самородного золота из россыпей Омолонского массива (Фомина, 2013). В зависимости от морфологии выделений, внутреннего строения, состава минералов-включений и пробности в россыпях и рудах выделены четыре его минеральных типа (Там же). Первый - высокопробное (800-980\%) медистое золото, связанное с комплексами архей-раннепротерозойского кристаллического фундамента. Второй - умеренновысокопробное (750-950\%) золото в ассоциации с минералами Те и $\mathrm{Bi}$, связанное с раннепалеозойскими гранитоидами. Золото третьего типа (700900\%о) ассоциирует с с теллуридами Au и Ag и связано с вулканитами кедонской серии. Низкопробное (300-550\%) золото четвертого типа связано с меловыми магматическими ассоциациями ОВП и ОЧВП. В шлихах с ним ассоциирует самородное серебро (Лушников, 1991).

Вещественные комплексы ПК вмещают разнообразные по составу и морфологии рудные проявления. Достаточно широко распространены жильные, штокверковые и стратиформные медные и полиметаллические рудопроявления, а также стратиформные железные руды. Наиболее многочисленные месторождения и рудопроявления золота, сопровождающиеся россыпями, принадлежат к золото-редкометалльной формации и сгруппированы в шесть золоторудно-россыпных узлов (см. рис. 2; табл. 3); четыре из них образуют Шаманихо-Столбовской рудно-россыпной район (далее - ШСР), в пределах которого сосредоточены все разведанные коренные месторождения и запасы россыпного золота. В минерагеническом отношении район принадлежит синаккреционному Яно-Колымскому мегапоясу (Горячев, 1998). Рудно-россыпные узлы ШСР (Глухаринский, Глуховский, Чилистяхский и Савельевский) приурочены к слабо вскрытым гранитоидным массивам и различаются по средним значениям крупности и пробности россыпного золота (0.73 мм и $870 \% ; 1.25$ мм и 900\%; 0.62 мм и $850 \%$ и 0.85 мм и $865 \%$ с соответственно). 


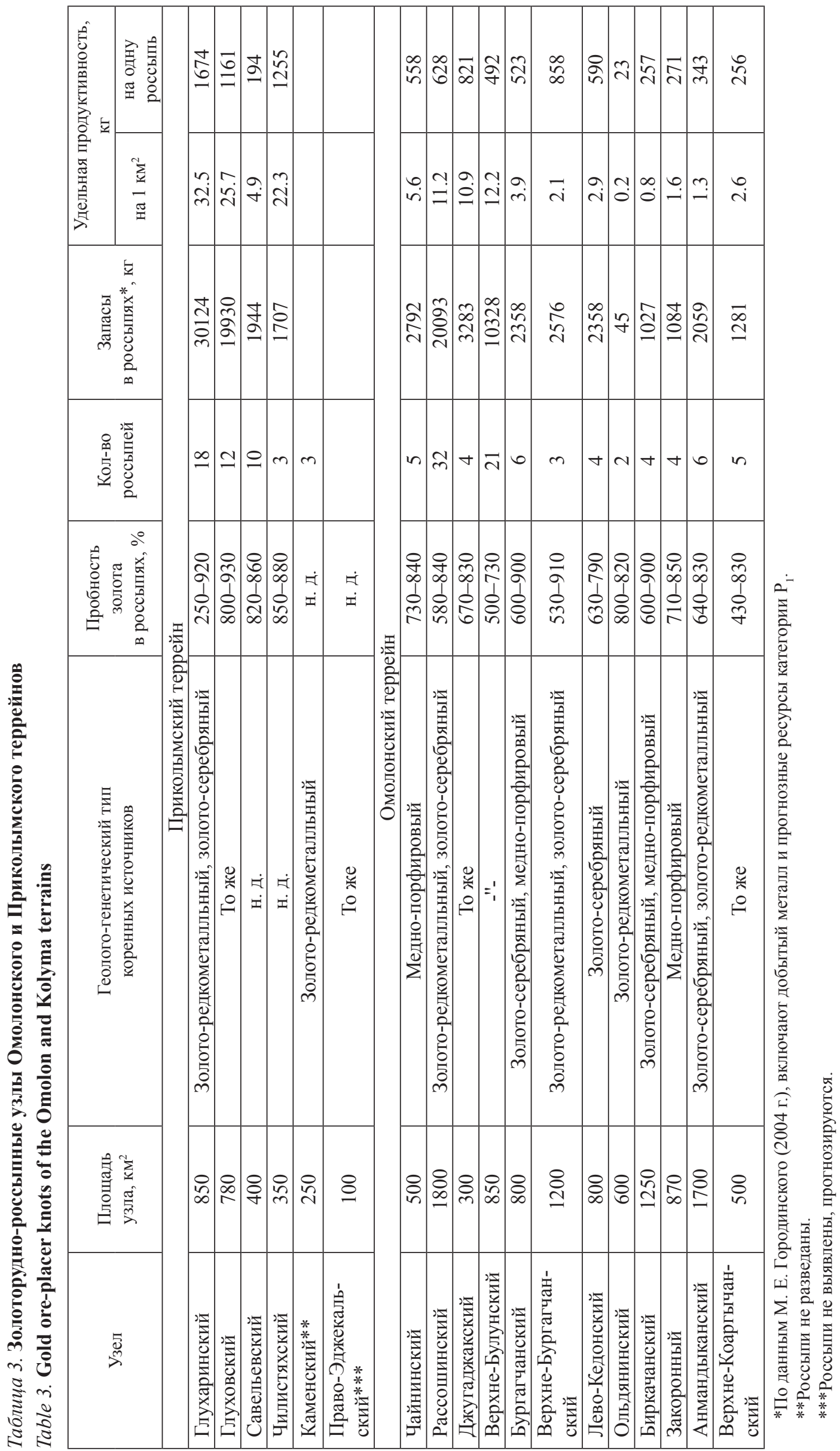


Размещение минерализации внутри узлов контролируется сопряжением надвигов с надынтрузивными зонами. Рудные тела приурочены к замковым частям крупных асимметричных антиклинальных складок, осложненных более поздними надвигами. Их взаимодействие с крутопадающими разрывами приводило к образованию структур объемного растяжения, благоприятных для формирования зон прожилкования. Другим важным рудоконтролирующим фактором являлся литологический - руды приурочены исключительно к тектоническим пластинам и линзам, сложенным хрупкими компетентными породами (кварцитами, метаморфизованными полевошпатово-кварцевыми песчаниками, риолитами, реже мраморами), «зажатым» среди пластичного тектонического матрикса (слюдистые сланцы, метабазиты). В роли геохимических барьеров для рудообразования выступали литологические границы между породами с различной зернистостью и степенью метаморфических преобразований, зоны интенсивных пластических деформаций с межслоевыми деформированными «альпийскими» жилами и прожилками, интенсивной трещиноватости и дробления. Сочетание тектонического и литологического факторов обусловило пологую стратоидную морфологию рудных тел, благоприятную для образования при их эрозии россыпей. Примером является месторождение Надежда, где рудные тела представлены пологими линзовидно-пластообразными зонами сульфидно-кварцевого прожилкования (Глухов, 2013; Глухов и др., 2016). Аналогичное геологическое строение имеют месторождения Тый-Юрье (Бирюков, 2017) и Сохатиное (Протопопов, 1994).

Золото-серебряное оруденение представлено пологими залежами брекчированных и окварцованных рифейских известняков и филлитов (рудопроявление Темное, Тимша) с акантитом, агвиларитом, киноварью, электрумом, кюстелитом.

Медно-порфировая формация Приколымья представлена, в первую очередь, рудопроявлениями Невидимка и Опыт (Шпикерман, 1998), образующими Право-Дуксундинский рудный узел (Глухов, Тюкова, 2013). Это штокверки сульфидно-серицит-кварцевого состава, сульфидно-карбонат-кварцевые жилы и залежи скарнов в окружении ореолов серицит-хлориткварцевых пропилитов.

Известные до настоящего времени проявления стратиформной свинцово-цинковой минерализации в карбонатных толщах сосредоточены на восточном фланге ПК и объединены в ярходонский рудный комплекс (Шпикерман, 1998; Глухов, Фомина, 2015). Рудные тела вмещаются рифейскими и палеозойскими доломитами и представлены пологими залежами интенсивно окварцованных тонкослоистых доломитов, содержащих послойную вкрапленность сульфидов.

Стратиформная медная минерализаџия широко распространена среди рифейских терригенно-карбонатных пород. Известны три рудопроявления и более двух десятков пунктов минерализации, объединенных В. И. Шпикерманом (1998) в Ороекскую металлогеническую зону. Медесодержащие горизонты вмещаются кварцхлоритоидными сланцами и прослеживаются по простиранию на первые километры.

Стратиформные гематитовые руды также широко развиты на Приколымье, приурочены к контактам сланцев и карбонатных пород и представлены, в первую очередь, месторождением Победа (Шпикерман, 1998).

Стратиформные залежи чеелит-сульфидных руд прогнозируются на западе ПК. Здесь нижнепротерозойские амфиболиты, плагиогнейсы и гнейсо-граниты сопровождаются обширными шлиховыми ореолами рассеяния шеелита.

Золотосодержашие конгломераты известны в основаниях разрезов девона и поздней юры (Литвиненко, 2007). Слабо окатанное золото крупностью менее 0.25 мм в ассоциации с пиритом, халькопиритом, арсенопиритом, галенитом, молибденитом присутствует как в гальке кварца, так и в цементе. Его источником, вероятно, послужило гипотетическое золото-квариевое оруденение, связанное с позднерифейским либо раннепалеозойским орогенезом.

В рудах и россыпях ПК выделяются четыре основных минеральных типа самородного золота (Глухов и др., 2018). Умеренно-высокопробное (790-920\%) золото в ассоциации с минералами Те и $\mathrm{Bi}$, так же как медистое высокопробное (950-980\%о) второго, связано с раннемеловыми золото-редкометалльными рудами и гранитоидами. Низкопробный (250-700\%о) металл, ассоциирующий с сульфоселенидами Ag и кюстелитом, связан с ранне-позднемеловым вулканизмом ОЧВП и Омсукчанского рифта. Источником перекристаллизованного высокопробного (750 980\%о) золота послужили золотоносные конгломераты.

Таким образом, ОМ и ПК существенно различаются набором геолого-генетических и структурно-морфологических типов минерализации. Для Приколымья типичны пологие рудовмещающие структуры и стратиформное оруденение; на Омолонском массиве, наоборот, развиты исключительно крутопадающие структуры значительной вертикальной протяженности, а стратиформное оруденение редуцировано. Так как главным полезным компонентом, определяющим металлогению обеих структур, является золото, попытаемся проследить, каким образом от- 
меченные различия выразились в характере его эндо- и экзогенных концентраций.

Следует учесть, что рассматриваемые террейны характеризуются неодинаковой и в целом неравномерной геологической изученностью, а их месторождения - разведанностью и промышленной освоенностью. Для учета этого обстоятельства в пределах каждого из них выделен ключевой район, где в течение многих десятилетий были сосредоточены основные объемы геологоразведочных и горноэксплуатационных работ. Эти геолого-экономические районы соответствуют металлогеническому таксону рудного района (Рудные..., 2001; Плющев и др., 2012, 2016). На Приколымье это Шаманихо-Столбовской рудно-россыпной район, где сосредоточены все разведанные золоторудные месторождения и россыпи, а в Омолонском массиве - Южно-Омолонский рудно-россыпной район (далее - ЮОР), объединяющий Биркачанский, Анмандыканский и Закоронный РРУ. Он включает, помимо россыпей, крупные золото-серебряные месторождения Кубака и Биркачан. Главным профильным полезным ископаемым обоих рудных районов является золото; серебро также извлекается из руд Кубаки и Биркачана, но в геохимическом (с учетом кларкового нормирования по Е. В. Плющеву (Рудные..., 2001) и стоимостном эквиваленте его роль ничтожна. Именно эти районы мы будем использовать для сопоставления.

В табл. 4 приведено сравнение количественных параметров золотоносности для каждого из террейнов в целом, а также для ключевых районов. В его основу положено количество добытого металла, разведанные запасы и прогнозные ресурсы категории $\mathrm{P}_{1}$. Анализ этих цифр показывает следующее. Общая золотоносность OM почти в 4 раза выше, чем ПК. В структуре золотоносноузлы.
Таблица 4. Количественные характеристики золотоносности Омолонского и Приколымского террейнов

Table 4. Qquantitative charasteristics of gold productivity of the Omolon and Kolyma terrains

\begin{tabular}{|c|c|c|}
\hline \multirow{2}{*}{ Параметры } & \multicolumn{2}{|c|}{ Террейн } \\
\hline & Омолонский & Приколымский \\
\hline \multicolumn{3}{|l|}{$\begin{array}{l}\text { Количество разведан- } \\
\text { ных и оцененных ме- } \\
\text { сторождений: }\end{array}$} \\
\hline рудных & 5 & 4 \\
\hline россыпных & 96 & 45 \\
\hline \multicolumn{3}{|l|}{ Суммарные запасы*, т: } \\
\hline рудных** & 187 & 16 \\
\hline россыпных *** & 50 & 53 \\
\hline $\begin{array}{l}\text { В том числе рудные } \\
\text { районы }\end{array}$ & $\begin{array}{c}\text { Южно- } \\
\text { Омолонский } * * * *\end{array}$ & $\begin{array}{l}\text { Шаманихо- } \\
\text { Столбовской }\end{array}$ \\
\hline \multicolumn{3}{|l|}{$\begin{array}{l}\text { Количество разведан- } \\
\text { ных и оцененных ме- } \\
\text { сторождений: }\end{array}$} \\
\hline рудных & 3 & 4 \\
\hline россыпных & 10 & 42 \\
\hline \multicolumn{3}{|l|}{ Суммарные запасы* ${ }^{*}$ т: } \\
\hline рудных** & 177 & 16 \\
\hline россыпных *** & 3 & 54 \\
\hline
\end{tabular}

*Включают разведанные запасы, прогнозные ресурсы категории $\mathrm{P}_{1}$ и количество добытого металла.

**По данным компании Polymetal International Plc.: https://www.polymetalinternational.com/ru/assets.

***По данным М. Е. Городинского (2004 г.).

****Включает Анмандыканский, Биркачанский и Закоронный рудно-россыпные

Таблицза 5. Прогнозный металлогенический потенциал Омолонского и Приколымского террейнов (Рудные..., 2001)

Table 5. Proposed metallogenic potential of the Omolon and Kolyma terrains ( Ore..., 2001)

\begin{tabular}{|l|c|c|}
\hline \multicolumn{1}{|c|}{ Параметры } & \multicolumn{2}{|c|}{ Террейн } \\
\cline { 2 - 3 } & Омолонский & Приколымский \\
\hline $\begin{array}{l}\text { Количество рудных } \\
\text { и рудно-россыпных узлов } \\
\text { В том числе высокопер- } \\
\text { спективных }\end{array}$ & 12 & 6 \\
\hline $\begin{array}{l}\text { Профиль РУ (по степени } \\
\text { промышленной значимо- } \\
\text { сти) }\end{array}$ & $\begin{array}{c}\mathrm{Au}, \mathrm{Ag}, \mathrm{Fe}, \mathrm{Mo}, \mathrm{Cu}, \\
\mathrm{Pb}, \mathrm{Zn}\end{array}$ & $\mathrm{Au}, \mathrm{Cu}, \mathrm{Pb}, \mathrm{Zn}, \mathrm{Fe}$ \\
\hline $\begin{array}{l}\text { Сумма прогнозных ресур- } \\
\text { сов условного Аu }\end{array}$ & 2454 & 33 \\
\hline
\end{tabular}


В то же время удельная продуктивность россыпей ПК (количество металла на одну россыпь и на единицу площади россыпных узлов) более чем вдвое выше, а все они сосредоточены в четырех пространственно сближенных россыпных узлах. Еще более информативным является сопоставление рудно-россыпных районов. Суммарные запасы рудного золота ЮОР в 11 раз превышают ШСР, а россыпного - в 17 раз уступают ему. Картину дополняет прогнозная оценка металлогенического потенциала ОМ и ПК (табл. 5), выполненная специалистами ВСЕГЕИ под руководством Е. В. Плющева (Рудные..., 2001; Плющев и др., 2012). Как видно, по прогнозным ресурсам Приколымье на два порядка уступает Омолонскому массиву. Полагаем, что приведенные цифры говорят сами за себя.

\section{ОБСУЖДЕНИЕ РЕЗУЛЬТАТОВ}

Попытаемся объяснить причины столь существенных различий. На первый взгляд, можно сделать вывод, что они заключаются в различных россыпеобразующих способностях золото-серебряной минерализации, определяющей металлогенический облик ОМ, и золоторедкометалльной, преобладающей на ПК. Однако, с одной стороны, на ПК золото-серебряное оруденение также присутствует и поставляет в россыпи определенное количество низкопробного металла (Прейс, Палымский, 1988; Глухов и др., 2018). С другой - и на ОМ умеренно-высокопробное золото, поступившее из золото-редкометалльных источников, играет существенную роль в балансе металла всех узлов (Показаньев и др., 1980; Лушников, 1991), а для некоторых - преобладает (например, Джугаджакский).

Воспользуемся подходом к анализу россыпной золотоносности, разработанным В. П. Полевановым (1988а,б, 1990). Этот исследователь рассматривал россыпные районы и провинции как самостоятельные металлогенические таксоны. Тектоническая структура интенсивно дислоцированных складчато-надвиговых поясов, характеризующаяся широким развитием складок и разрывов, способствовала формированию рассеянной золотой минерализации, благоприятной для россыпеобразования. Напротив, жесткие, консолидированные региональные структуры с немногочисленными крупными разломами являются благоприятными для концентрации эндогенного оруденения с образованием крупных коренных месторождений. В этом контексте ПК наследует общую для Яно-Колымского металлогенического мегапояса специфику, который представляет собой золотороссыпную (выделено мною. $-A$. Г.) провинцию в понимании В. П. Полеванова (1988б).
Таким образом, ПК может рассматриваться как золотороссыпная, т. е. с экстенсивной золотой минерализацией металлогеническая зона, а ОМ - золоторудная, т. е. с концентрированным оруденением. Обусловлено это принципиальными различиями тектонической структуры и геодинамической природы этих террейнов, которые, с позиций геодинамической систематики рудоносных структур (Старостин, 1990), определили диаметрально отличные режимы рудообразования. ПК представляет собой составной террейн надвигового строения, формирование структуры которого происходило почти непрерывно, начиная с раннего протерозоя и до кайнозоя включительно (Прокопьев и др., 2019). Эпизоды сжатия, сопровождавшиеся складко- и надвигообразованием, разделялись длительными эпохами медленного растяжения. С позиций геодинамической систематики рудоносных структур (Старостин, 1990) такой режим соответствует классу сдвигов и надвигов. Мобильная геологическая структура ПК с преобладанием пологих надвигов способствовала последовательному усилению неоднородности состава литосферы и неоднократной реювенации рудного вещества. В соответствии с «первым законом рудообразования» Л. Н. Овчинникова (рудообразование есть переход металлов от рассеяния к концентрации; 1986) минерализация, в отсутствие магистральной рудоконтролирующей структуры, концентрировалась на множестве «частных» структурных и литологических (надвиговые пластины) барьеров, формируя разрозненные скопления. Каждое из них в отдельности могло обладать высоким кларком концентрации, однако в сколь-нибудь значимом объеме геологического пространства средние содержания полезного компонента оказывались низкими. При таком сценарии формировалось множество мелких рудоконцентраций, что благоприятствовало образованию россыпей; формирование богатого оруденения было маловероятно (Абрамович, 1998).

Напротив, ОМ представляет собой жесткую структуру, консолидированную уже к началу рифея. На протяжении всей дальнейшей геологической летописи он сохранял свое внутреннее строение. Многочисленные эпохи сжатия и растяжения на протяжении фанерозоя существенно не изменили структурный рисунок ОМ и лишь способствовали формированию субвертикальных расколов кристаллического фундамента, по которым наложенные тектоно-магматические процессы проникали далеко в глубь массива (Кузнецов, 2006), формируя объекты с концентрированным оруденением. Подобный геодинамический режим относится к классу блоковых штампов (Старостин, 1990). По мнению И. И. Абрамовича и И. Г. Клушина (1987), в условиях высокой вариа- 
тивности температур и давлений, которая является следствием частых структурных подвижек, могут формироваться лишь мелкие и бедные месторождения; для формирования же крупных и богатых объектов необходима стабильность геодинамического режима. Консолидированный характер дорифейского фундамента ОМ сделал также невозможным формирование так называемых структур латерального выжимания и сменяющих их в пространстве «геодинамических убежищ», вмещающих орогенные золото-кварцевые месторождения (Корольков, 2007). Это обьясняет отсутствие на ОМ синаккреционного позднеюрскораннемелового оруденения.

\section{ЗАКЛЮЧЕНИЕ}

Многие черты металлогении региональных структур объясняются особенностями их тектоники и геодинамической эволюции. Наиболее контрастно это проявляется у докембрийских террейнов по причине длительной истории их геологического развития, охватившей несколько эпох тектогенеза. Продуктивность золоторуднороссыпных узлов служит одним из количественных параметров металлоносности, который находится в зависимости от тектоники, в частности, наличия либо отсутствия консолидированного дорифейского фундамента и, как следствие, подвижности либо, наоборот, стабильности региональной структуры. Эта зависимость реализуется через морфологию и условия залегания рудных тел и рудоконтролирующих разломов, глубину их проникновения, спектр геолого-генетических типов минерализации и ее богатство.

\section{ЛИТЕРАТУРА}

Абрамович И. И. Геодинамика и мантийные корни рудных формаций. Москва: МПР, Геокарт, 1998. 140 с.

Абрамович И. И., Клушин И. Г. Геодинамика и металлогения складчатых областей. Ленинград : Недра, 1987. $247 \mathrm{c}$.

Акинин В. В., Жуланова И. Л. Возраст и геохимия циркона из древнейших метаморфических пород Омолонского массива (Северо-Восток России) // Геохимия. 2016. № 8. С. 675-684.

Беус В. А., Миледин А. К. Новые данные о возрасте метаморфического комплекса Приколымского поднятия // ДАН СССР. 1990. Т. 311, № 4. С. 925-928.

Бибикова Е. В., Макаров В. А., Грачева Т. В., Сеславинский Т. Б. Возраст древнейших пород Омолонского массива // ДАН СССР. 1978. Т. 241. № 2. С. 434-436.

Бирюков A. А. Месторождение Тый-Юрья - новый золоторудный объект на Приколымском террейне // Чтения памяти академика К. В. Симакова : Материалы докладов Всерос. науч. конф. (Магадан, 22-24 нояб. 2017 г.). Магадан : ИП Жарикова Т. П., 2017. C. 76-78.

Булгакова М. Д. Ранний - средний палеозой Северо-Востока СССР (седиментологический анализ). Якутск: ЯНЦ СО АН СССР, 1991. 104 с.
Волков А. В., Сидоров А. А., Савва Н. Е., Прокофьев В. Ю., Колова Е. Е., Мурашов К. Ю., Земскова $M$. И. Особенности эпитермального рудообразования в Кедонском палеозойском вулканоплутоническом поясе Северо-Востока России, по данным геохимических исследований $\mathrm{Au}-\mathrm{Ag}$ оруденения // Вулканология и сейсмология. 2016. № 6. С. 3-21. DOI: 10.7868/ S0203030616060079.

Гагиева А. М., Жуланова И. Л. Геохронометрия среднепалеозойских вулканитов Омолонского массива: сопоставление K-Ar, Rb-Sr, U-Pb данных, геологическая интерпретация (Северо-Восток Азии) // Тихоокеанская геология. 2011. Т. 30, № 3. С. 3-19.

Геодинамика, магматизм и металлогения Востока России: в 2 кн. Владивосток : Дальнаука, 2006. Кн. 1. C. $1-572$.

Глухов А. Н. Геологическое строение и состав руд золоторудного месторождения Надежда // Отечественная геология. 2013. № 4. С. 7-17.

Глухов А. Н. Тектонические факторы рудогенеза докембрийских террейнов на примере Приколымского поднятия и Омолонского массива (Северо-Восток Азии) // Вестник СПбГУ. Науки о Земле. 2019. Т. 64. Вып. 2. С. 219-248.

Глухов А. Н., Тюкова Е. Э. Перспективы развития минерально-сырьевой базы меди Магаданской области // Руды и металлы. 2013. № 5. С. 21-33.

Глухов А. Н., Фомина М. И. Новые данные о стратиформной полиметаллической минерализации в карбонатных толщах Приколымского террейна // Отечественная геология. 2015. № 3. С. 37-44.

Глухов А. Н., Гладков А. С., Кошкарев Д. А., Лунина $O$. $B$. Тектонофизические критерии геодинамической эволюции Приколымского террейна (Северо-Восток России) // Геодинамика и тектонофизика. 2012. Т. 3. № 4. C. 361-375.

Глухов А. Н., Савва Н. Е., Буляков Г. Х., Фомина M. И., Бирюков А. А. Самородное золото в рудах и россыпях Глухаринского узла, Магаданская область // Руды и металлы. 2018. № 2. С. 55-65.

Глухов А. Н., Савва Н. Е., Колова Е. Е. Вещественный состав и генезис золотых руд месторождения Надежда, Магаданская область // Руды и металлы. 2016. № 4. C. 60-71.

Горячев H. A. Геология мезозойских золотокварцевых жильных поясов Северо-Востока Азии. Магадан : СВКНИИ ДВО РАН, 1998. 210 с.

Горячев Н. А., Егоров В. Н., Савва Н. Е., Кузнецов В. М., Фомина М. И., Рожков П. Ю. Геология и металлогения фанерозойских комплексов юга Омолонского массива. Владивосток : Дальнаука, 2017. 312 с.

Дылевский Е. Ф. Айэнэнский интрузив и особенности его щелочных сиенитов // Магматизм и оруденение Северо-Востока России. Магадан : СВКНИИ ДВО РАН, 1997. С. 108-134.

Жуланова И. Л. Земная кора Северо-Востока Азии в докембрии и фанерозое. Москва: Наука, 1990. 304 с.

Кораго Е. А., Льчагин П. П. Особенности среднепалеозойских вулканитов Омолонского массива и перспективы связанного с ним медно-молибденового оруденения // Вопросы геологии срединных массивов Северо-Востока СССР. Магадан : СВКНИИ ДВНЦ AH CCCP, 1977. C. 99-103. 
Корольков А. Т. Геодинамика золоторудных районов Восточной Сибири. Иркутск : Изд-во ИГУ, 2007. $251 \mathrm{c}$.

Кузнеиов B. M. Разнопорядковые структуры тектоно-магматической активизации в ВерхояноЧукотской складчатой области // Вестник СВНЦ ДВО PAH. 2006. № 2. C. 2-12.

Литвиненко И. С. Геохимия и парагенезис самородного золота россыпных месторождений ШаманихоСтолбовского района // Чтения памяти акад. К. В. Симакова : тез. докл. Всерос. науч. конф. Магадан : СВНЦ ДВО РАН, 2007. С. 95-96.

Лушников Л. А. Некоторые поисковые критерии россыпной золотоносности Кедон-Коркодонского района Омолонского срединного массива // Материалы по геологии и полезным ископаемым СевероВостока СССР. Магадан : Кн. изд-во, 1991. Вып. 27. C. 224-235.

Мерзляков В. М., Дылевский Е. Ф., Лычагин П. П., Терехов М. И. Тектоника, магматизм и металлогения Омолонского срединного массива // Геология и полезные ископаемые Северо-Востока Азии. Владивосток : ДВНЦ АН СССР, 1984. С. 140-151.

Овчинников Л. Н. Геохимические основы поисков рудных месторождений // Геохимия в локальном металлогеническом анализе. Новосибирск : ИГиГ СО AH CCCP, 1986. C. 3-4.

Овчинников Л. Н. Прикладная геохимия. М. : Недра, 1990. 248 с.

Петрищевский А. М. Колымо-Омолонская плита обособленный литосферный фрагмент // Региональные проблемы. 2015. Т. 18, № 1. С. 3-20.

Плющев Е. В., Кашин С. В., Соловьев Н. С. Месторождения, рудные узлы и металлогенические зоны как компоненты иерархической металлогенической системы // Региональная геология и металлогения. 2016. № 65. С. 71-83.

Плющев Е. В., Шатов В. В., Кашин С. В. Металлогения гидротермально-метасоматических образований. Санкт-Петербург : Изд-во ВСЕГЕИ, 2012. 560 с.

Показаньев В. П., Вялов А. Г., Пчелинцевва Р. 3. Вопросы металлогении Абкитского плутона // Материалы по геологии и полезным ископаемым СевероВостока СССР. Магадан : Кн. изд-во, 1980. Вып. 25. C. $130-137$.

Полеванов B. П. Золотороссыпные провинции как самостоятельные структурно-металлогенические зоны // Колыма. 1988б. № 9. С. 10-13.

Полеванов В. П. Некоторые закономерности локализации россыпей золота юго-востока ИньялиДебинского синклинория // Колыма. 1988а. № 4. C. 8-11.

Полеванов В. П. Россыпеобразующие золоторудные формации и их продуктивность // Там же. 1990. № 6. С. 5-8.

Прейс В. К., Пальммский Б. Ф. Минералогия самородного золота одной из россыпей Приколымского горст-антиклинория // Там же. 1988. № 4. С. 11-13.

Прокопьев А. В., Ершова В. Б., Стокли Д. (U/Th)/ Не низкотемпературная термохронология обломочных цирконов (ZHe) из осадочных пород южной части Приколымского террейна (Верхояно-Колымская складчатая область) // Геология и минеральносырьевые ресурсы Северо-Востока России : материа- лы IX Bсерос. науч.-практ. конф : в 2-х т. Якутск : Издат. дом СВФУ, 2019. Т. 1. С. 114-117.

Протопопов Г. И. Первые находки рудного золота в Шаманихо-Столбовском золотороссыпном районе Северо-Востока России // Руды и металлы. 1994. № 3. C. 31-32.

Poccbinные месторождения России и других стран СНГ (минерагения, промышленные типы, стратегия развития минерально-сырьевой базы). Москва : Науч. мир, 1997. 479 с.

Pудные узлы России. Санкт-Петербург : ВСЕГЕИ, 2001. $416 \mathrm{c}$.

Савва Н. Е., Прейс В. К. Атлас самородного золота Северо-Востока СССР. Москва : Наука, 1990. 292 с.

Савва Н. Е., Шахтыров В. Г. Золото-серебряное месторождение Ольча : тектоническая позиция, структура и минералогическая характеристика // Геология рудных месторождений. 2011. Т. 53, № 5. С. 462-486.

Сидоров А. А., Волков А. В. Металлогения окраинноморской литосферы (Северо-Восток России) // Литосфера. 2015. № 1. С. 24-34.

Сидоров А. А., Волков А. В., Алексеев В. Ю. О металлогении кратонных террейнов и районов «пологих дислокаций» на Северо-Востоке России // Доклады Академии наук. 2008. Т. 423, № 6. С. 783-786.

Сидоров А. А., Чехов А. Д., Волков А. В. О металлогенической эволюции палеоокраинноморской литосферы мезозоид Северо-Востока Азии // Вестник СВНЦ ДВО РАН. 2012. № 1. С. 2-7.

Смелов А. П., Тимофеев В. Ф. Террейновый анализ и геодинамическая модель формирования СевероАзиатского кратона в раннем докембрии // Тихоокеанская геология. 2003. Т. 22, № 6. С. 42-54.

Старостин В. И. Геодинамические типы рудоносных структур // Вестник Моск. ун-та. Сер. 4. Геология. 1990. № 3. С. 28-47.

Степанов В. А., Мельников А. В. О продуктивности рудно-россыпных узлов Приамурской золотоносной провинции // Разведка и охрана недр. 2017. № 1. C. 8-19.

Степанов В. А., Шишакова Л. Н. Кубакинское золото-серебряное месторождение. Владивосток : Дальнаука, 1994. 195 с.

Тектоника, геодинамика и металлогения территории Республики Саха (Якутия). Москва : МАИК «Наука / Интерпериодика», 2001. 571 с.

Толпегин Ю. Г., Генкин П. О. Основные черты геоморфологии и россыпной золотоносности Юкагирского плоскогорья // Колыма. 1974. № 5. С. 32-34.

Третьяков А. В. Закономерности россыпной золотоносности востока Казахстана // Известия НАН РК. Сер. геол. 2010. № 1. С. 39-45.

Третьяков $\Phi$. $Ф$. О тектоническом строении Приколымского террейна Верхояно-Колымской орогенной области (структурно-статистический анализ) // Отечественная геология. 2016. № 6. С. 85-90.

Трунилина В. А., Орлов Ю. С., Роев С. П. Магматические ассоциации Уяндино-Ясачненского вулканоплутонического пояса и его геодинамическая природа // Там же. 2004. № 4. С. 61-67.

Фадеев А. П. Железорудные проявления ЮжноОмолонского района // Колыма. 1975. № 6. С. 41-43.

Фомина М. И. Типоморфные особенности самородного золота на Омолонском массиве // Материалы 
Всерос. конф. «Рудообразующие процессы: от генетических концепций к прогнозу и открытию новых рудных провинций и месторождений». Москва : ИГЕМ PAH, 2013. C. 113.

Хаин В. Е., Филатова Н. И., Полякова И. Д. Тектоника, геодинамика и перспективы нефтегазоносности Восточно-Арктических морей и их континентального обрамления. Москва : Наука, 2009. 227 с. (Тр. ГИН РАН; вып. 601).

Худолей А. К., Ткаченко В. И., Матуков Д. И., Бережная Н. Г., Сергеев С. А. Новые данные о возрасте докембрийских вулканитов хакдонской серии (Восточное Приколымье) // Доклады Академии наук. 2006. Т. 411, № 4. С. 505-509.

Черняев Е. В., Черняева Е. И. Структура и условия локализации золотого оруденения Кубакинского рудного поля // Известия Томского политех. ун-та. 2001. С. 225-243. (Т. 304. Вып. 23: Геология, поиски и разведка полезных ископаемых Сибири).

Шевченко В. М. Архей и протерозой Омолонского массива. Петрология и изотопный возраст. Магадан : СВНЦ ДВО РАН, 2006. 176 с.
Шпикерман В. И. Домеловая минерагения СевероВостока Азии. Магадан : СВКНИИ ДВО РАН, 1998. $333 \mathrm{c}$.

Шпикерман В. И., Горячев Н. А., Егоров В. Н. О силурийском тектогенезе, магматизме и метаморфизме на Северо-Востоке Азии // Проблемы геологии и металлогении Северо-Востока Азии на рубеже тысячелетий. Магадан : СВКНИИ ДВО РАН, 2001. Т. 1. C. 102-103.

Щеглов А. Д. Современное состояние теоретических основ металлогении. Ленинград : Институт естествознания и техники АН СССР, 1989. 24 с.

Щербакова И. П., Березнер О. С., Беус В. А., Ткаченко В. И. Дорифейский метаморфический комплекс в Приколымье // Магматические и метаморфические комплексы Северо-Востока СССР и составление Госгеолкарты-50. Магадан : СВКНИИ ДВО АН СССР, 1988. C. 75-76.

Kiselev A. I., Kochnev B. B., Yarmolyuk V. V., Rogov V. I., Egorov K. N. The Early Paleozoic magmatism in the northeastern Siberian craton // Geodynamics \& Tectonophysics. 2016.7 (2). P. 233-250.

Поступила в редакиию 09.07.2019 2.

Поступила после доработки 10.10.2019 2.

\title{
PRODUCTIVITY OF GOLD-ORE AREAS OF THE OMOLON AND KOLYMA TERRAINS (Northeast Asia)
}

\begin{abstract}
A. N. Glukhov
North-East Interdisciplinary Scientific Research Institute n. a. N. A. Shilo, FEB RAS, Magadan

The article considers the influence of tectonics and geodynamic evolution of pre-Cambrian terrains on ore and placer productivity, which is exemplified by the Omolon massif and the Kolyma elevation. It briefly characterizes geologic-genetic types of mineralization and presents parameters of oreplacer knots. It is shown that the Omolon massif is a gold-ore metallogenic zone, while the Kolyma elevation is a gold-placer one, which is caused by fundamental differences in the tectonic structures and the geodynamic histories of the terrains: the terrain former is a rigid structure consolidated by the early Neoproterozoic; the latter, the composite terrain, is structurally similar to a fold-thrust belt. The author concludes that many features of the Precambrian terrains metallogeny are explained by peculiarities of their tectonic evolution. In particular, productivity of gold ore-placer knots depends on of the availability of the consolidated Preriphean basement. This dependence is carried out through morphology and conditions of ore bodies and ore-controlling faults deposition, their penetration depth, the range geologic and genetic types of gold mineralization, and its richness.
\end{abstract}

Keywords: gold placer, lode gold, terrain, productivity, ore forming, Precambrian, consolidated, thrust-faulted, metallogenic.

\section{REFERENCES}

Abramovich, I. I., 1998. Geodynamics and Mantle Roots of the Mineral Deposit Types. St. Petersburg, Geokart [In Russian].

Abramovich, I. I., Klushin, I. G., 1987. Geodynamics and Metallogeny of Fold Belts. Leningrad, Nedra [In Russian].

Akinin, V. V., Zhulanova, I. L., 2016. Age and Geochemistry of Zircon from Oldest Metamorphic Rocks of the Omolon Massif (Northeast Russia), Geochemistry International. 54 (8), 651-659.
Beus, V. A., Miledin, A. K., 1990. New Data on the Age of Metamorphic Complex of the Kolyma Elevation, Doklady Akademiyi Nauk SSSR. 311 (2), 925-928 [In Russian].

Bibikova, E. V., Makarov, V. A., Gracheva, T. V., Seslavinskiy, T. B., 1978. The Age of the Omolon Massif Oldest Rocks, Ibid. 241 (2), 434-436 [In Russian].

Birukov, A. A., 2017. Tiy-Yurya Deposit: New Gold Ore Object at the Prikolymsky Terrain, Conference Delicated to the Memory of Academician K. V. Sima- 
kov : Conference Proceedings (Magadan, November 2224, 2017). Magadan, NEISRI FEB RAS, 76-78 [In Russian].

Bulgakova, M. D., 1991. Early - Middle Paleozoic of North-East of the USSR (Sedimentology Analysis). Yakutsk, YSC AS USSR [In Russian].

Cherniaev, E. V., Cherniaeva, E. I., 2001. Structure and Localization of Gold Mineralization of the Kubaka Gold Field, Bulletin of the Tomsk Polytechnic UniversityGeo Assets Engineering. 304 (23), 225-243 [In Russian].

Fadeev, A. P., 1975. Iron Mineralization of South Omolon District, Kolyma. 6, 41-43 [In Russian].

Fomina, M. I., 2013. Typomorphic Peculiarities of Native Gold at the Omolon Massif, Proceedings of AllRussia Conference "Ore-Forming Processes from Model to Forecasting”. Moscow, IGEM, 113 [In Russian].

Gagieva, A. M., Zhulanova, I. L., 2011. Geochronometry of the Middle Paleozoic Volcanites of the Omolon Massif in Northeast Asia: Comparison of the K-Ar, Rb-Sr, and U-Pb Data and Their Geological Interpretation, Russian Journal of Pacific Geology. 5 (3), 181-198.

Glukhov, A. N., 2013. Geological Structure and Ore Composition of the Nadezhda Gold Deposit (Magadan Oblast), Otechestvennaya Geologiya. 4, 7-17 [In Russian].

Glukhov, A. N., 2019. Tectonic Framework for Metallogeny of Precambrian Structures on the Example Kolyma and Omolon Terrains (North-East of the Asia), Vestnik of SaintPetersburg University, Earth Sciences. 64 (2), 219-248.

Glukhov, A. N., Fomina, M. I., 2015. New Data no Stratiform Polymetallic Mineralization in Carbonate Rocks of the Kolyma Terrain, Otechestvennaya Geologya. (3), 37-44 [In Russian].

Glukhov, A. N., Gladkov, A. S., Koshkarev, D. A., Lunina, O. V., 2012. Tectonophysical Evidences of Geodynamic Evolution of the Kolyma Terrain (North-Eastern Regions of Russia), Geodynamics \& Tectonophysics. 3 (4), 361-375. DOI: 10.5800/GT2012340079 [In Russian].

Glukhov, A. N., Tuykova, E. E., 2013. Prospects for Developing Copper Resources in Magadan Oblast, Rudy $i$ Metally. 5, 21-33 [In Russian].

Glukhov, A. N., Savva, N. E., Bulyakov, G. H., Fomina, M. I., Biryukov, A. A., 2018. Native Gold in Ores and Placers of the Glukhariny Knot, Magadan Oblast, Ibid. 2, 55-64 [In Russian].

Glukhov, A. N., Savva, N. E., Kolova, E. E., 2016. Ore Mineralogy and Genesis of the Nadezhda Gold Deposit, Magadan Oblast, Ibid. 4, 60-71 [In Russian].

Goryachev, N. A., 1998. Geology of Mesozoic GoldQuartz Lode Belts in the North-East of Asia. Magadan, NEISRI FEB RAS [In Russian].

Goryachev, N. A., Yegorov, V. N., Savva, N. E., Kuznetsov, V. M., Fomina, M. I., Rozhkov, P. Yu., 2017. Geology and Metallogeny of Phanerozoic Assemblages in the South of the Omolon Microcontinent. Vladivostok, Dal'nauka [In Russian].

Dylevsky, E. F., 1997. Ayenensk Intrusion and Some Features of Its Alcalic Syenites, Magmatism and Mineralization of Russia's North-East. Magadan, NEISRI FEB RAS, 108-134 [In Russian].

Khain, V. E., Filatova, N. I., Polyakova, I. D., 2009. Tectonics, Geodinamics, and Petroleum Potential of the Eastern Arctic Seas and Their Continental Framing,
Transactions of the Geological Institute, 601. Moscow, Nauka [In Russian].

Khudoley, A. K., Tkachenko, V. I., Matukov, D. I., Berezhnaya, N. G., Sergeev, S. A., 2006. New Age Data on Precambrian Volcanic Rocks of the Khakdon Group, Eastern Kolyma Region, Doklady Earth Sciences. 411 (9), 1357-1361.

Kiselev, A. I., Kochnev, B. B., Yarmolyuk, V. V., Rogov, V. I., Egorov, K. N., 2016. The Early Paleozoic Magmatism in the Northeastern Siberian Craton, Geodynamics \& Tectonophysics, 7 (2), 233-250.

Korago, E. A., Lychagin, P. P., 1977. Peculiarities of Middle-Paleozoic Volcanic Units of the Omolon Massif and Prospects of the Associated Moly-Copper Mineralization, Issues in Geology of the Stable Massifs of the North-East of the USSR. Magadan, SVKNII DVNC AN USSR, 99-103 [In Russian].

Korolkov, A. T., 2007. Geodynamics of Gold-Ore Districts in East Siberia. Irkutsk, Irkutsk University [In Russian].

Kuznetsov, V. M., 2006. Different-Scale Structures of Tectonic and Magmatic Activization of the VerkhoyanskChukotka Folding Belt, Vestnik NESC FEB RAS. 2, 2-12

[In Russian].

Litvinenko, I. S., 2007. Geochemistry and Paragenesis of Native Qold of Placer Deposits of the ShamanikhaStolbovskoy District, Conference Delicated to the Memory of Academician K. V. Simakov, Proceedings (Magadan, November 27-29, 2007). Magadan, NESC FEB RAS, 9596 [In Russian].

Lushnikov, L. A., 1991. Some Exploration Criteria for Gold Placers of Kedon-Korkodon District of the Omolon Median Massif, Materials on Geology and Mineralization of the North-East of the USSR. Magadan, 27, 224-235 [In Russian].

Merzlyakov, V. M., Dylevskiy, E. F., Lychagin, P. P., Terekhov, M. I., 1984. Tectonics, Magmatizm, and Metallogeny of the Omolon Median Massif, Geology and Minerals of the North-East of Asia. Vladivostok, FESC AS USSR [In Russian].

Ore Knots of Russia, 2001. St. Petersburg, VSEGEI ([In Russian].

Ovchinnikov, L. N., 1986. Geochemical Foundations of Ore Deposit Exploration, Geochemistry in Local Metallogenic Analysis. Novosibirsk, SO AN SSSR, 3-4 [In Russian].

Ovchinnikov, L. N., 1990. Applied Geochemistry. Moscow, Nedra [In Russian].

Placer Deposits of Russia and Other CIS Countries, 1997. Moscow, Scientific World [In Russian].

Petrishchevsky, A. M., 2015. Kolyma-Omolon Plate Separate Fragment of Lithosphere, Regional'nye Problemy. 18 (1), 3-20 [In Russian].

Plyuschev, E. V., Kashin, S. V., Solovyov, N. S., 2016. Ore Deposits, Clusters, and Metallogenic Zones as Components of the Hierarchic Metallogenic System, Regional Geology and Metallogeny. 65, 71-83 [In Russian].

Plyuschev, E. V., Shatov, V. V., Kashin, S. V., 2012. Metallogeny of Hydrothermal-Altered Rocks. St. Petersburg, VSEGEI [In Russian].

Pokazanyev, V. P., Vyalov, A. G., Pchelintseva, R. Z., 1980. Issues in Metallogeny of the Abkit Pluton, Materi- 
als on Geology and Mineralization of the North-East of the USSR. Magadan, 25, 130-137 [In Russian].

Polevanov, V. P., 1988. Some Regularities of Localization of Gold Placers in the South-East of the Inyali-Debin Synclinorium, Kolyma. 4, 8-11 [In Russian].

Polevanov, V. P., 1988. Gold-Placer Provinces as Autonomous Structural and Metallogenic Zones, Kolyma. 9, 10-13 [In Russian].

Polevanov, V. P., 1990. Placer-Formative Types of Gold Mineralization and Their Productivity, Ibid. 6, 5-8 [In Russian].

Preys, V. K., Palymskiy, B. F., 1988. Mineralogy of Native Gold from One of the of the Kolyma Horst Anticlinorium Placers, Ibid. 4, 1113 [In Russian].

Prokopyev, A. V., Yershova, V. B., Stokley, D., 2019. (U/Th)/He Low-Temperature Thermocronology of Detrital Zircons (ZHe) from the Sedimentary Rocks of South Part of Kolyma Terrain, Geology and Mineral Resources of the North-East of the Russia, Proceedings of IX AllRussia Conference. Yakutsk, North-East Federal University, 1, 114-117 [In Russia].

Protopopov, G. I., 1994. The First Discoveries of Ore Gold in the Shamanikha-Stolbovaya Gold Placer District, Rudy i Metally. 3, 31-32 [In Russian].

Savva, N. E., Preys, V. K., 1990. Atlas of Native Gold of the North-East of the USSR. Moscow, Nauka [In Russian].

Savva, N. E., Shakhtyrov, V. G., 2011. The Ol'cha GoldSilver Deposit: Tectonic Setting, Structure, and Mineralogy, Geology of Ore Deposits. 53 (5), 412-433.

Shcheglov, A. D., 1989. Modern Theoretical Foundations of Metallogeny. Leningrad, Institut Estestvoznaniia i Tekhniki AN SSSR [In Russian].

Shevchenko, V. M., 2006. Archaean and Proterozoic of the Omolon Massif, Petrology and Isotopic Age. Magadan, NESC FEB RAS [In Russian].

Shcherbakova, I. P., Berezner, O. S., Beus, V. A., Tkachenko, V. I., 1988. Early Precambrian Metamorphic Complex in Prikolymye, Magmatic and Metamorphic Complexes of North-East of the USSR and Compiling Federal Geological Map 50. Magadan, SVKNII DVO AN USSR, 75-76 [In Russian].

Shpikerman, V. I., 1998. Pre-Cretaceous Metallogeny of Northeast Asia. Magadan, NEISRI FEB RAS [In Russian].

Shpikerman, V. I., Goryachev, N. A., Yegorov, V. N., 2001. On Silurian Tectogenesys, Magmatism, and Metamor-phism in the North-East of Asia. Problems of Geology and Metallogeny in Northeast Asia in the New Millenium, Magadan, NEISRI FEB RAS [In Russian].

Sidorov, A. A., 1998. Ore Formations and Historical Analysis of Precious Metals Mineralization. Magadan, NEISRI FEB RAS [In Russian].

Sidorov, A. A., Chekhov, A. D., Volkov, A. V., 2012. On Metallogenical Evolution of the Mesozoid Marginal Sea Lithosphere (Northeast Russia), Vestnik NESC FEB RAS. 1, 2-7 [In Russian].
Sidorov, A. A., Volkov, A. V., 2015. Metallogeny of the Marginal Sea Lithosphere (Northeast Russia), Litosfera. 1, 24-34 [In Russian].

Sidorov, A. A., Volkov, A. V., Alekseev, V. Yu., 2008. Metallogeny of Craton Terrains and "Shallow Dislocation" Areas in the North-East of the Russia, Doklady Akademii Nauk. 423 (6), 783-786 [In Russian].

Smelov, A. P., Timofeyev, V. F., 2003. Terrain Analysis and the Geodynamic Model of the North Asian Craton Formation in Early Precambrian, Russian Journal of Pacific Geology. 22 (6), 42-54 [In Russian\}.

Starostin, V. I., 1990. Geodynamic Types of Ore-Bearing Structures, Bulletin of Moscow State University, Geology. 3, 28-47 [In Russian].

Stepanov, V. A., Mel'nikov, A. V., 2016. On the Productivity of Ore-Placer Knots in the Amur Gold Province, Prospect and Protection of Mineral Resources. 1, 8-19 [In Russian].

Stepanov, V. A., Shishakova, L. N., 1994. Kubaka Gold-Silver Deposit. Vladivostok, Dal'nauka [In Russian].

Tectonics, Geodynamics, and Metallogeny of the Sakha Republic (Yakutia), 2001. MAIK "Nauka / Interperiodica”. Moscow [In Russian].

Tolpegin, Yu. G., Genkin, P. O., 1974. Main Features of Geomorphology and Gold Placers of the Yukagir Upland, Kolyma. 5, 32-34 [In Russian].

Tretyiakov, A. V., 2010. Regularities in Gold Placers of the East of Kazakhstan, Bulletin of National Academy of Science of Kazakhstan, Geology. 1, 39-45 [In Russian].

Tretyiakov, F. F., 2016. Tectonic Structure of the Kolyma Terrain of the Verkhoyano-Kolyma Orogenic Belt, Structural-Statistic Analysis, Otechestvennaya Geologya. 6, 85-90 [In Russian].

Trunilina, V. A., Orlov, Yu. S., Roev, S. P., 2004. Magmatic Associations of the Uyandina-Yasachnaya Volcanic Belt and Its Geodynamical Nature, Ibid. 4, 61-67 [In Russian].

Volkov, A. V., Sidorov, A. A., Savva, N. E., Prokofyev, V. Yu., Kolova, E. E., Murashov, K. Yu., Shevchenko V. M., 2006. Archaean and Proterozoic Rocks of the Omolon Massif - Petrology and Isotope Age. Magadan, NESC FEB RAS [In Russian].

Volkov, A. V., Sidorov, A. A., Savva, N. E,. Prokofyev, V. Yu., Kolova, E. E., Murashov, K. Yu., Zemskova, M. I., 2016. Epithermal Mineralization in the Kedon Paleozoic Volcano-Plutonic Belt, Northeast Russia, Geochemical Studies of Au-Ag Mineralization, Journal of Volcanology and Seismology. 11(1), 1-19 [In Russian].

Zemskova, M. I., 2016. Epithermal Mineralization in the Kedon Paleozoic Volcano-Plutonic Belt, Northeast Russia: Geochemical Studies of Au-Ag Mineralization, Ibid. 11 (1), 1-19.

Zhulanova, I. L., 1990. The Earth Crust of Northeast Asia - in Precambrian and Phanerozoy. Moscow, Nauka [In Russian]. 